\title{
Isolation of Neospora caninum from a calf in Malaysia
}

\begin{abstract}
In order to attempt isolate the protozoan parasite Neospora caninum, an $\mathrm{N}$. caninum seropositive pregnant Sahiwal Friesian cross heifer from a large-scale dairy farm in Malaysia was kept for observation until parturition at the Veterinary Research Institute, Ipoh. The heifer gave birth to a female calf that was weak, underweight and unable to rise. Precolostral serum from the calf had an $\mathrm{N}$. caninum indirect fluorescent antibody test titre of 1:3200. It died $12 \mathrm{~h}$ after birth and necropsy was performed. Brain homogenate from the calf was inoculated into $10 \mathrm{BALB} / \mathrm{c}$ mice that were kept for 3 months after which brain tissue from the mice was inoculated onto $24 \mathrm{~h}$ fresh monolayer Vero cell lines. The cell cultures were examined daily until growth of intracellular protozoa was observed. DNA of the organisms from the cell cultures was analyzed by PCR and DNA sequencing. DNA fragments of the expected size were amplified from the isolate using $\mathrm{N}$. caninum-specific primers, and sequence analysis of ITS1 clearly identified the isolate as N. caninum. This is the first successful isolation of $\mathrm{N}$. caninum from a bovine in Malaysia, and the isolate is designated Nc-MalB1.
\end{abstract}

Keyword: Neospora caninum, Cattle-protozoa, Isolation, Malaysia 